\title{
Local distribution patterns of harvestmen (Arachnida: Opiliones) in a Northern temperate Biosphere Reserve landscape: influence of orientation and soil richness
}

\author{
Izaskun Merino-Sáinz \& Araceli Anadón*
}

\author{
Departamento de Biología de Organismos y Sistemas, Universidad de Oviedo, C/ Catedrático Rodrigo Uría s/n, 33071 \\ Oviedo (Asturias, Spain) \\ * Corresponding author: Araceli Anadón, e-mail: aanadon@uniovi.es
}

\begin{abstract}
The study at a local scale of the fauna in a natural mountain landscape provides insights regarding the patterns and the factors influencing distribution. We test if each type of natural forest and some open habitats in the Muniellos Biosphere Reserve have their own unique harvestmen assemblages. We further investigate the presence of groups of sites sharing harvestmen assemblages and the factors and indicator species involved. Nineteen sites with well-known phytosociological association were sampled during nine surveys from late 2001 to 2002 by means of three sampling protocols. The quality of the inventories was assessed via the corresponding species accumulation curves. The cluster analysis using the Bray Curtis similarity index showed the presence of two main distinct groups of sites. One group consisted of seven lower forest sites, while the second group contained samples from more open sites and lighter forests. IndVal analyses show the first group has six characteristic species and the second group has one. ANOSIM analyses revealed that the harvestmen community composition was significantly different between the two clusters. Orientation appears to be one main driver of harvestmen assemblages on Mount Muniellos: a clear distinction between the two clusters appears along the boundary of shady to sunny habitats. The vegetal associations that house the higher harvestmen species richness have the higher soil richness. Seven rare and infrequent species were found in forests with richer soil.
\end{abstract}

KEY WORDS: Arthropoda, vegetation, diversity, assemblages, Spain.

\section{INTRODUCTION}

There is a need to measure and describe natural and disturbed landscapes in order to relate distribution patterns to their causes and consequences (RICKLEFS 1987). The level of species diversity in a particular area represents a balance between regional processes, such as dispersal and species formation, and local processes, such as biotic interactions and stochasticity (RICKLEFS 1987, 2004; WIENS \& DONOGHUE 2004).

Determining landscape patterns at small 'microlandscape' scales can potentially serve as a model for larger-scale landscape systems (MiLne 1988). One of the advantages is that measurements may be taken with a level of detail that is difficult to attain at a broader scale. Specific results can provide evidence of the factors influencing distribution in addition to suggestions regarding the mechanisms through which patterns may arise.

CuRTIS \& MACHADO (2007) described the ecology of harvestmen focusing on spatial and temporal patterns in the occurrences of harvestmen species and the assemblages of species in natural environments. These can be described and compared using simple parameters such as species composition, species richness and the relative abundance of each species. So far, only one study on the Iberian Peninsula has followed this approach (RAMBLA 1985). Some recent papers on the ecology of Opiliones have tested the type of distribution of particular species 
(LIPOVSEK et al. 1996; MitOV 1997), biotope preferences (STOL 2003, 2004), ecological profiles (MITOV \& STOYANOV 2005), patterns of distribution (KOMPOSCH 2000; MUSTER 2001; ACOSTA \& GUERRERO 2011), the study of natural reserves (ZINGERLE 1997, 1999) and faunistic similarity among different islands (TSURUSAKI et al. 2005) and forests (PINTO-DA-ROCHA \& DA SILVA 2005), the relationship between elevation and harvestmen species richness (KOMPOSCH \& GRUBER 1999; ALMEIDA-NETO et al. 2006), the role of fragmentation (BRAGAGNOLO et al. 2007) and the influence of grazing history in harvestmen biodiversity (PASCHETTA et al. 2013).

The Muniellos Biosphere Reserve in Asturias, Northern Spain, is mainly covered by forests and has barely been exposed to human influence due to its geographical isolation and rugged landscape. It may be considered "near-natural" (i.e. pristine) in the sense of PETERKEN (1993) and is therefore considered a site of special scientific interest. Sampling was carried out at nineteen sites of a well-known vegetation type at microscale resolution in order to elaborate the
Muniellos Inventory of Invertebrates (ANADÓN et al. 2002). As the basic data on harvestmen fauna are already known (MERINO SÁINZ \& ANADÓN 2008, 2009) it is possible to study their spatial patterns. All the sites in the lower altitudes of Mount Muniellos are in close vicinity to each other, composing a mosaic within one square kilometer. So we studied their distribution at a local microscale level.

Here, we tested if each type of natural forest and some open habitats in the Muniellos Biosphere Reserve have their own unique harvestmen assemblages. We further investigated the presence of groups of sites sharing harvestmen assemblages and the factors and indicator species involved.

\section{MATERIALS AND METHODS}

\section{Study area}

The Muniellos Biosphere Reserve (Fig. 1) is situated in Cangas del Narcea (Asturias, North-

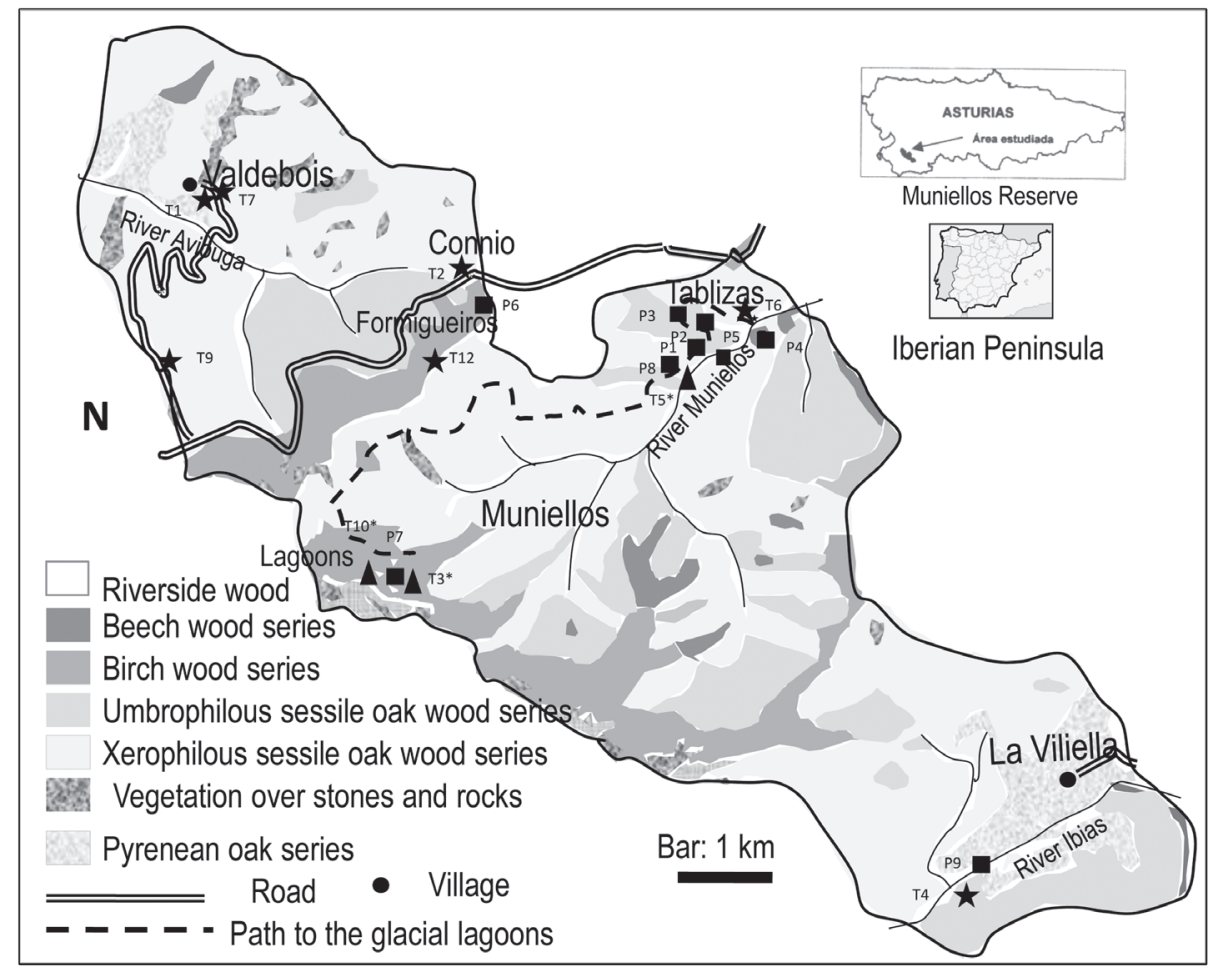

Fig. 1. - Map of Muniellos Biosphere Reserve with the sites studied. Main vegetation series are depicted in

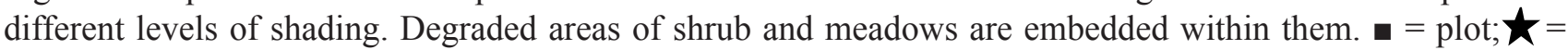
transect; $\boldsymbol{\Delta}=$ transect with pitfall trap. Birch trees predominate at high altitudes, sessile oaks in lower areas. 
Western Spain). It contains three drainage basins with acid Palaeozoic Variscan rocks and a very thin layer of soil. The basins surprisingly are locally named mountains. The climate of the reserve is temperate oceanic. Mount Muniellos has an upper humid ombrotype, steep slopes and three glacial lagoons and has been a protected area since 1964. Mount La Viliella and Mount Valdebois have a humid ombrotype, slighter slopes and each one contains a very small village. The climate belt is mainly montane (FERNÁNDEZ PRIETO \& BUENO SÁNCHEZ 1996).

Phytogeographically, the reserve belongs to the Orocantabrian Province, Atlantic Superprovince, within the Eurosiberian Region (DÍAZ GonZÁleZ \& FERNÁNDEZ PRIETO 1994), on the border with the Mediterranean Region. Mature forests (Principado Asturias 2001) cover $67 \%$ of the reserve, with sessile oak (Quercus petraea) forests $(2,900 \mathrm{ha})$ predominating at lower altitudes and birch (Betula celtiberica) forests (507 ha) at higher altitudes. Beech (Fagus sylvatica) forests in more humid areas, Pyrenean oak (Quercus pyrenaica) forests in warmer areas and two types of gallery forests complete the mature woodlands, while different types of shrubland occupy $18 \%$ of the surface. Erica australis subsp. aragonensis, red heath shrubs, cover $9 \%$ of the reserve. Mixed forests including maples (Acer pseudoplatanus) and sessile oaks cover particularly small territories with richer soils originating from landslides.

\section{Sampling sites and collecting methods}

Eight plots and twelve transects were selected based on their vegetation type to study the invertebrates (OCHARAN et al. 2003) of the reserve (Fig. 1, Table 1). The sites were situated on a wide range of altitudes and included twelve forests, four shrublands, two grasslands and a peatbog. The nine sampling periods started at the following time periods: 10th November in 2000; 29th April, 18th June, 6th August, and 25th October in 2001; and 18th February, 16th April, 1st July and 26th September in 2002 (for details, see ANADÓN et al. 2002). Each sampling period lasted two weeks and was carried out by at least five individuals with no specialization in harvestmen. Each individual used the same sampling method within all localities and periods.

Three sampling protocols were applied. Plots (P) of $50 \mathrm{~m} \times 50 \mathrm{~m}$ were sampled by four active sampling methods, each method for one hour: capture with entomological net, vegetation sweeping with an entomological net, direct capture and beating; and by three additional passive methods: Malaise trap, seven pitfall traps and soil extraction by Berlese funnels. The protocol for each transect $(\mathrm{T})$ included the first three aforementioned sampling methods for one hour. In addition, three transects $\left(\mathrm{T}^{*}\right)$ were also sampled with pitfall traps. The pitfall traps had no bait, only water and sodium polyphosphate. They were active for two days in 2000 and five days in 2001 and 2002.

\section{Data analyses}

All specimens of harvestmen were identified and catalogued, along with their localities, date and sampling method (MERINO SÁINZ \& ANADÓN 2008, 2009). This material is deposited in the BOS-Opi 1-493 and BOSOpi 931 Arthropod Collections, Department of Biology of Organisms and Systems, University of Oviedo, Spain (MERINO-SÁINZ et al. 2013).

The diversity was studied as species richness and as true diversity, ${ }^{2} D=1 / \lambda$ (HILL 1973; JOST 2007; TUOMISTO 2010) with $\lambda=\sum_{i=1}^{s} p_{i}^{2}$, pi being the proportional abundance of the $i$ th species. True beta diversity is the quotient between the true gamma diversity of a data set and the average true alpha diversity of all the compositional units; here, the sampling sites: ${ }^{2} D_{\beta}={ }^{2} D_{\gamma} /{ }^{2} \overline{D_{\alpha}}$.

PRIMER V6 program (CLARKE \& GORLEY 2006) was used to obtain species accumulation curves, hierarchical clustering (CLUSTER), multidimensional scaling (MDS), analysis of similarity (ANOSIM), and similarity percentage 


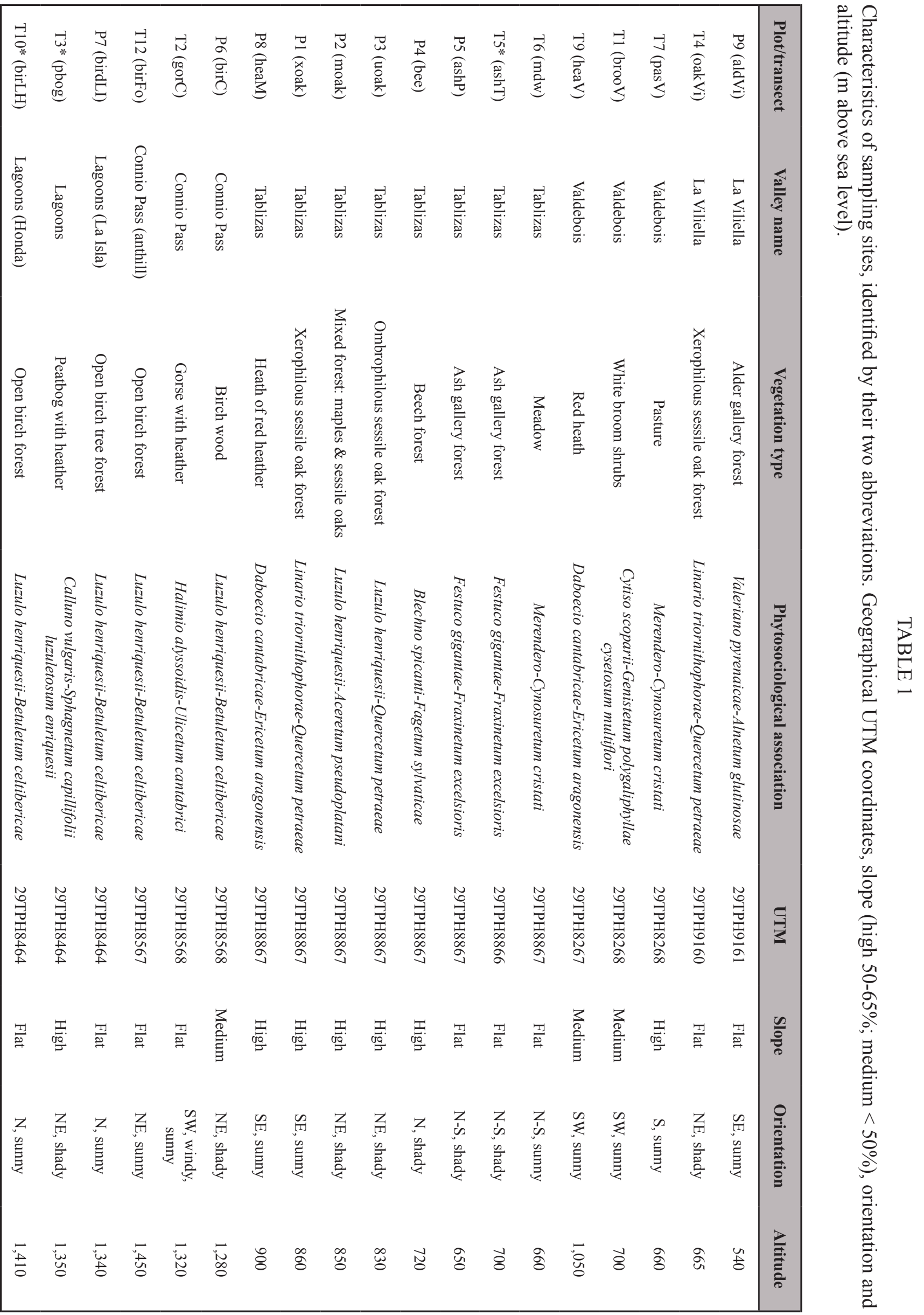


analysis (SIMPER). The species accumulation curves assess the quality of the inventory. The sampling dates (in the case of captures) were taken as measures of sampling effort and were randomized 999 times. The asymptotes of the curves were estimated fitting the Clench function to the smoothed curves by means of a Simplex and Quasi-Newton method (HORTAL et al. 2004) using the Statistica v6 program (StatSoft 2001). The function provides a good fit when $R^{2}$ approaches 1 (JIMÉNEZ-VALVERDE \& HORTAL 2003). The asymptote of the curves, being the point where the slope reaches 0 (HORTAL et al. 2004), predicts the estimated species richness of each sufficiently well-sampled site. When the value of the final slope is lower than 0.1 and the percentage of collected species is over 70 , the inventory is considered reliable and the community to be well sampled (HORTAL \& LOBO 2005). Moreover, five non-parametric estimates of total species richness: Jacknife 2, Jacknife 1, Chao 1, Chao 2, and Bootstrap were obtained.

Although three different sampling protocols were applied, no sites and data were discarded a priori from the Basic Data table.

We conducted an ANalysis Of SIMilarity (ANOSIM) (CLARKE \& GORLEY 2006) to test for significant differences in harvestmen assemblages between each pair of sites and between the two main clusters of sites based on a permutation test. To estimate beta diversity, the distance between two sites based on the Bray-Curtis coefficient of similarity was calculated on the square root transformed abundance data. Triangular matrices of the distances across sampling sites (according to their species assemblages) were used in the hierarchical clustering (CLUSTER), carried out with average group linkage, and in a nonmetric multidimensional scaling (MDS), which represents the distances among the sites in a geometric space.

The similarity percentage analysis (SIMPER) identifies the species primarily providing the discrimination of similarity or dissimilarity between two observed sample clusters.
Specificity and fidelity of each harvestmen species within the groups of sites were explored via the indicator value index (IndVal) (DUFRÊNE \& LEGENDRE 1997; DE CÁCERES \& LEGENDRE 2009), which measure the association of a species for a given clustering of sites. Indicator species are defined as the most characteristic species for a cluster of sites and it is most frequent in this cluster and present in the majority of sites belonging to that cluster (DUFRÊNE \& LEGENDRE 1997). Indicator species analyses were run using the package "indicspecies" 1.7.3 2014-07-10 (DE CÁCERES \& JANSEN 2014) in R (R Development Core Team 2012).

Species richness in terms of vegetation was studied qualitatively (see CURTIS \& MACHADO 2007), scoring the richness and abundance present in forested versus open areas and the different types of forests and their situation on the mountain: gallery, mountainside, sunny, shady, low, medium or high.

\section{RESULTS}

A total of 765 individual Opiliones were sampled in the Muniellos Biosphere Reserve, belonging to 19 different species, with a true diversity of 8.34 effective species (Table 2). Average number of species per site was 7 species. True $\beta$ diversity is $8.34 / 4.0=2.09$ compositional units in the dataset. The estimation of global species richness with non-parametric estimators ranged between 20.6 using Bootstrap $(\mathrm{q}=0.92)$ and 24.9 using Jacknife 2 (Fig. 2).

Pitfall traps, sweeping, hand picking and beating resulted in $40 \%, 34.9 \%, 18.7 \%$ and $5.8 \%$ of the specimens.

The overall inventory is sufficiently reliable (Table 3).

However, the asymptotes at each particular site are generally far from the observed richness value, and suggest that $<70 \%$ of the species were captured. 


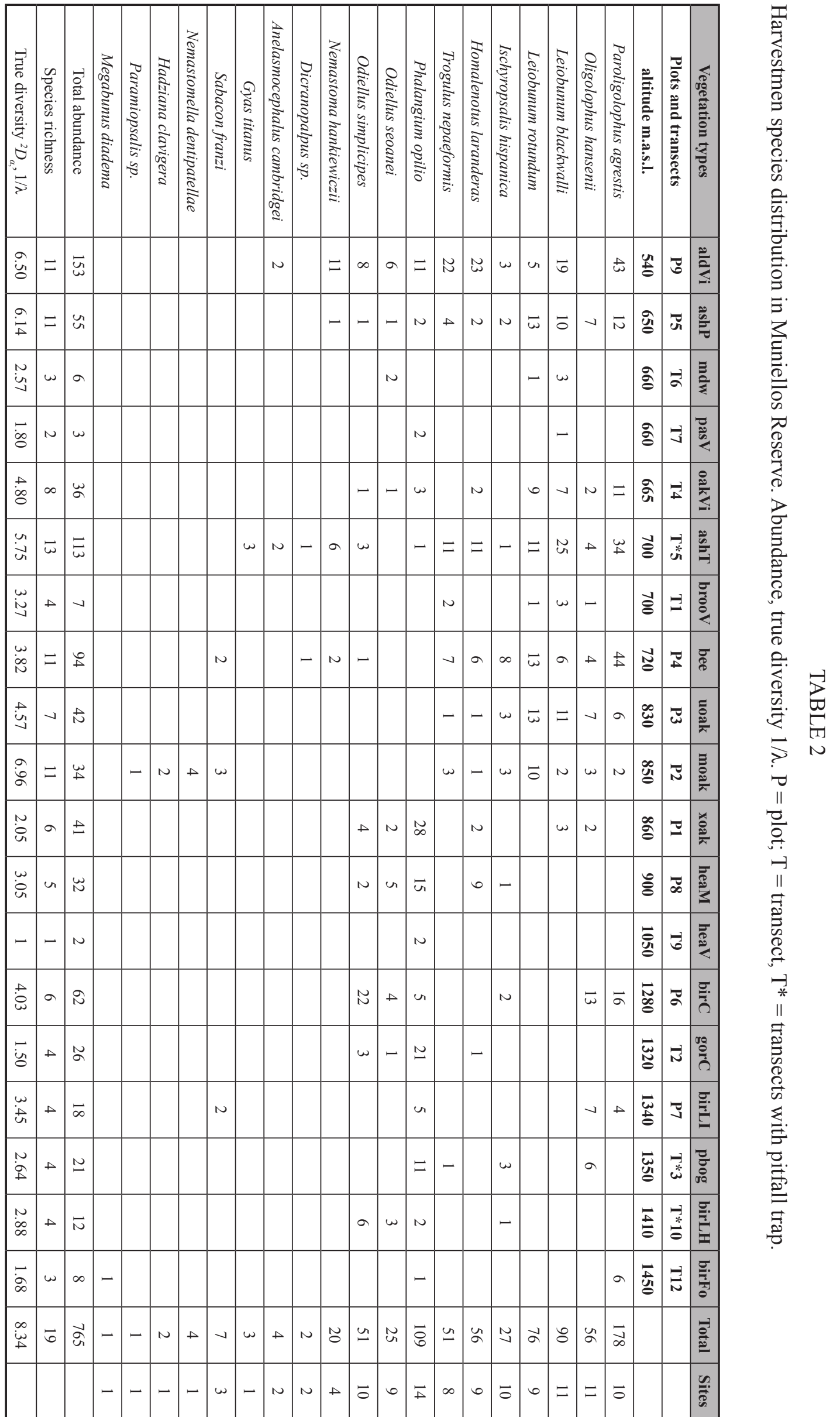




\section{TABLE 3}

Species richness ( $\mathrm{S}$ ): raw data and accumulation curves. $\mathrm{N}=$ sampling units; $\mathrm{R}^{2}=$ curves coefficient of determination; $\mathrm{ES}=$ estimated species richness; $\%, \mathrm{~S} / \mathrm{ES}=\%$ species collected; $\mathrm{p}=$ final slope of the species accumulation curve ( 0 indicates a perfect inventory).

\begin{tabular}{|cccccccc|}
\hline Plots \& transects & $\mathbf{N}$ & $\mathbf{S}$ & Abundance & $\mathbf{R}^{\mathbf{2}}$ & $\mathbf{E S}$ & \%S/ES & $\mathbf{p}$ \\
\hline P1 xoak & 20 & 5 & 39 & 0.997 & 6.38 & 78.4 & 0.05 \\
P2 moak & 16 & 11 & 33 & 0.999 & 18.84 & 58.4 & 0.28 \\
P3 uoak & 15 & 7 & 42 & 0.999 & 9.07 & 77.2 & 0.1 \\
P4 bee & 16 & 11 & 94 & 0.999 & 16.2 & 67.9 & 0.22 \\
P5 ashP & 14 & 11 & 55 & 0.999 & 17.69 & 62.2 & 0.298 \\
P6 birC & 13 & 6 & 62 & 0.989 & 7.3 & 82.2 & 0.07 \\
P7 birLI & 9 & 4 & 18 & 0.998 & 5.45 & 73.4 & 0.12 \\
P8 heaM & 16 & 5 & 32 & 0.996 & 6.8 & 73.5 & 0.08 \\
P9 aldVi & 17 & 11 & 153 & 0.989 & 13.5 & 81.5 & 0.1 \\
T1 brooV & 3 & 4 & 7 & 0.998 & 11.18 & 35.78 & 0.85 \\
T2 gorC & 5 & 4 & 26 & 0.999 & 7.33 & 54.57 & 0.36 \\
T*3 pbog & 8 & 4 & 21 & 0.999 & 5.25 & 76.19 & 0.12 \\
T4 oakVi & 12 & 8 & 36 & 0.998 & 11.9 & 67.23 & 0.21 \\
T*5 ashT & 21 & 13 & 113 & 0.998 & 17.06 & 76.2 & 0.15 \\
T6 mdw & 4 & 3 & 6 & 0.99 & 5.48 & 54.74 & 0.34 \\
T*10 birLH & 5 & 4 & 12 & 0.998 & 6.02 & 66.44 & 0.27 \\
All plots & 136 & 17 & 528 & 0.976 & 17.5 & 97.1 & 0.009 \\
All transects & 63 & 15 & 234 & 0.995 & 16.54 & 90.69 & 0.03 \\
\hline All plots \& transects & 199 & 19 & 762 & 0.956 & 19.46 & 97.64 & 0.006 \\
\hline
\end{tabular}

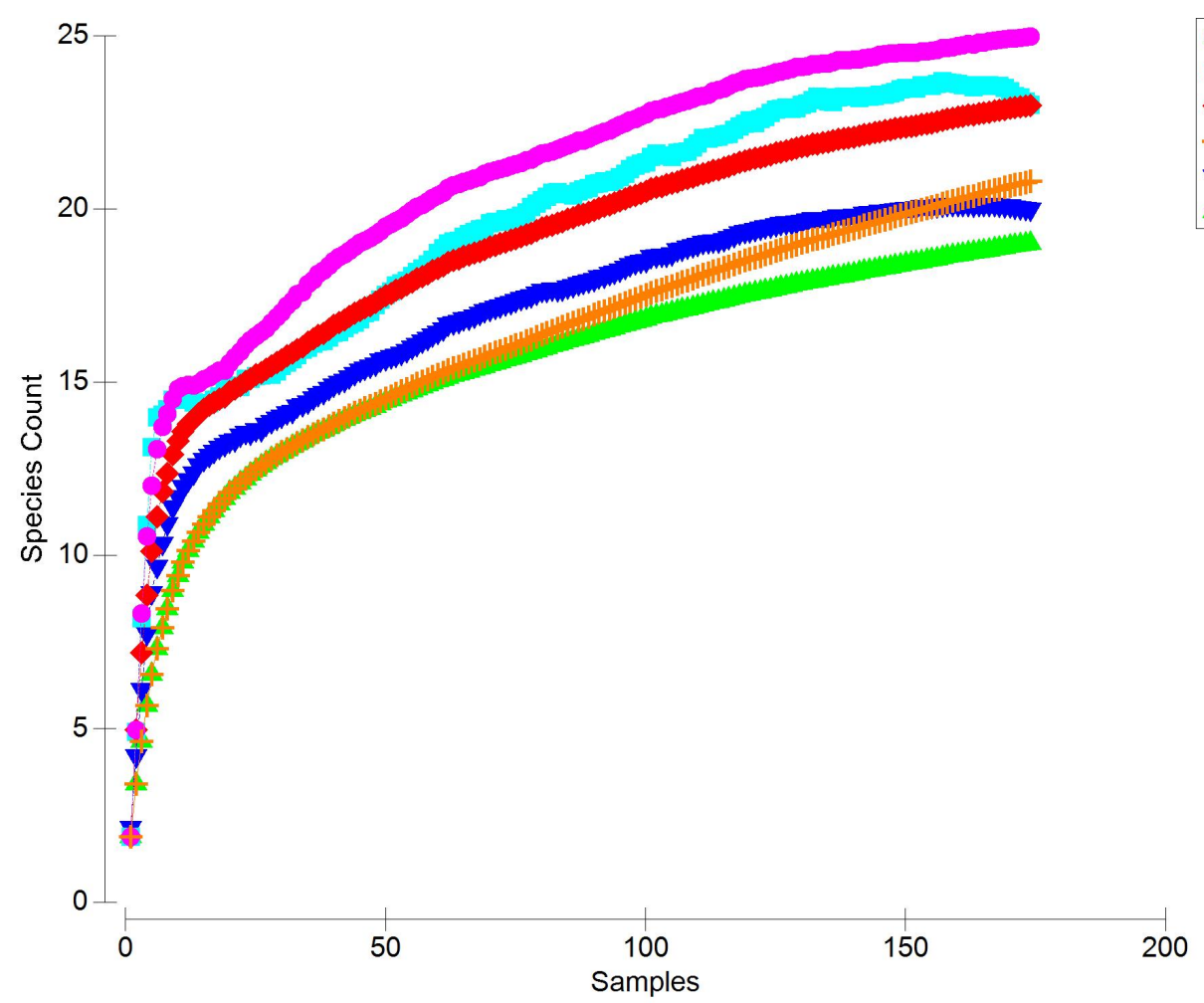

Fig. 2. - Species accumulation curve for observed (Sobs) Opiliones of all plots and transects together, and for 5 different non-parametric estimators of species richness: Bootstrap, Chao 1, Chao 2, Jacknife 1 and Jacknife 2. Sobs is closest to Chao 2 and Bootstrap estimator. 


\section{Cluster analyses, MDSs and ANOSIM and SIMPER of the sites}

The cluster analysis of the sites based on their species composition returned two distinct groups (A1 and A2; Fig. 3). A1 includes seven low-altitude forest sites: ash gallery forest, alder gallery forest, beech forest, mixed forest of maples and sessile oaks, ombrophilous sessile oak forest, and "xerophilous" sessile oak forest of La Viliella. These forests are shady to different degrees and have higher harvestmen species richness (7-13 species/site), as well as higher average true alpha diversity 5.5 (3.82-6.96 effective species/site). Only the alder gallery forest is sunnier due to the width of the river.

Cluster A2 contained seven sites: the xerophilous sessile oak forest of Muniellos, two shrublands (heather and gorse) and one birch forest (subcluster A2.1) and two other birch forests and the peatbog (subcluster A2.2). All are higher-altitude sunny sites with 4-6 species richness with a lower average true diversity of $2.8(1.50-4.03)$ species per site.

Clusters D1 and D2 contained pasture T7, heathland $\mathrm{T} 9$ and high birch forest T12. Cluster

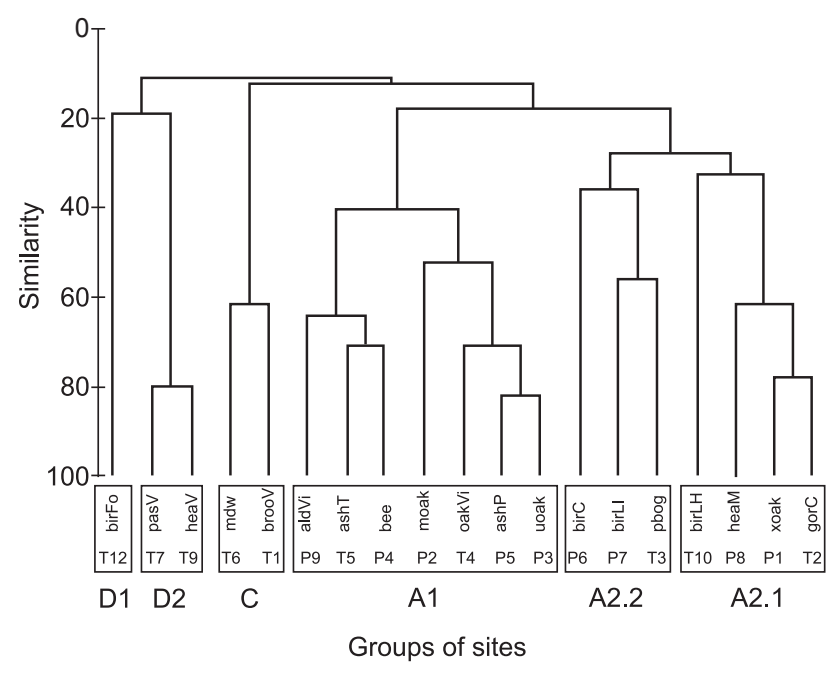

Fig. 3. - Cluster analysis of sites attending their harvestmen assemblages. Groups of sites A1 and A2 are supported by ANOSIM values and indicator species.
C contained a meadow and a shrub with brooms. The meadow T6 in the core of the reserve appeared very poor in harvestmen and yielded very few specimens represented by only three species. All these sites of the last three clusters had in common few harvestmen specimens sampled and only 1-4 species.

MDS of Fig. 4 show the vegetation structure and the groups of sites. Forest sites are spread along the space and distributed in different clusters.

The similarity analyses (ANOSIM) between pairs of sites of the main clusters are summarized in Table 4. Differences were consistently found between sites belonging to the different clusters $\mathrm{A} 1$ and A2, but not between sites within one cluster. Hence, the assemblages in one cluster of sites differ from the assemblages in the other cluster of sites, but do not differ among themselves. Some exceptions can be found in P6 and P7, and P9. An ANOSIM test that evaluated all possible permutations (1716) between clusters $\mathrm{A} 1$ and $\mathrm{A} 2$, each with seven sites, revealed that the correlation in species composition within clusters equaled $r=0.766$, which was significantly different from a random distribution $(\mathrm{P}<0.001)$. These results prove the existence in Muniellos Biosphere Reserve of two major clusters of sites with different harvestmen assemblages. Similarity percentage analyses (SIMPER) (Table 5) gives the contribution of the species to internal similarity of the main clusters. The ANOSIM results table does not include T1, T6*, T7, T9 and T12 (with $\leq 8$ specimens): no differences between them and any other site were detected.

The study of indicator species values (IndVal) of the groups of sites (Table 6) gave six indicator species for cluster A1 and one indicator species for cluster A2. The values of specificity and fidelity were very high. Cluster D1, D2 and $\mathrm{C}$ had no species associated. No species was simultaneously associated to two, three of four clusters of sites. 


\section{TABLE 4}

ANOSIM analysis of differences in species composition: * = differences $\mathrm{p} \leq 0.05 ; * *=$ differences $\mathrm{p} \leq 0.01$; $* * *=$ differences $\mathrm{p} \leq 0.001$.

\begin{tabular}{|c|c|c|c|c|c|c|c|c|c|c|c|c|c|}
\hline Cluster & Site & & $\begin{array}{l}\text { A1 } \\
\text { P5 }\end{array}$ & $\begin{array}{l}\text { A1 } \\
\text { P2 }\end{array}$ & $\begin{array}{l}\text { A1 } \\
\text { P4 }\end{array}$ & $\begin{array}{l}\text { A1 } \\
\text { P3 }\end{array}$ & $\begin{array}{l}\text { A1 } \\
\text { P9 }\end{array}$ & $\begin{array}{l}\text { A2 } \\
\text { P6 }\end{array}$ & $\begin{array}{l}\text { A2 } \\
\text { P7 }\end{array}$ & $\begin{array}{l}\text { A2 } \\
\text { P1 }\end{array}$ & $\begin{array}{l}\text { A2 } \\
\text { P8 }\end{array}$ & $\begin{array}{l}\text { A2 } \\
\text { T3* }\end{array}$ & $\begin{array}{c}\mathrm{A} 2 \\
\mathrm{~T} * 10\end{array}$ \\
\hline & & Veg. & ashP & moak & bee & uoak & aldVi & birC & birLI & xoak & heaM & pbog & birLH \\
\hline A1 & P5 & $\operatorname{ash} \mathrm{P}$ & I & 0 & 0 & 0 & 0 & $*$ & $* *$ & $* * *$ & $* * *$ & $* *$ & $* *$ \\
\hline $\mathrm{A} 1$ & P2 & moak & 0 & I & 0 & 0 & 0 & $* *$ & $*$ & $* * *$ & $* * *$ & $*$ & $* * *$ \\
\hline $\mathrm{A} 1$ & P4 & bee & 0 & 0 & I & 0 & $* *$ & $* * *$ & $* * *$ & $* * *$ & $* * *$ & $* *$ & $* * *$ \\
\hline $\mathrm{A} 1$ & P3 & uoak & 0 & 0 & 0 & I & $* *$ & $* *$ & $*$ & $* * *$ & $* * *$ & $* *$ & $* * *$ \\
\hline $\mathrm{A} 1$ & P9 & aldVi & 0 & 0 & $* *$ & $* *$ & I & $*$ & $* * *$ & $* * *$ & $* *$ & $* *$ & $* *$ \\
\hline A2 & P6 & birC & $*$ & $* *$ & $* * *$ & $* *$ & $*$ & I & 0 & $*$ & $*$ & $*$ & 0 \\
\hline A2 & P7 & birLI & $* *$ & $*$ & $* * *$ & $*$ & $* * *$ & 0 & I & 0 & 0 & 0 & $*$ \\
\hline A2 & $\mathrm{P} 1$ & xoak & $* * *$ & $* * *$ & $* * *$ & $* * *$ & $* * *$ & $*$ & 0 & I & 0 & 0 & 0 \\
\hline A2 & P8 & heaM & $* * *$ & $* * *$ & $* * *$ & $* * *$ & $* *$ & $*$ & 0 & 0 & I & 0 & 0 \\
\hline A2 & $\mathrm{T}^{*} 10$ & birLH & $* *$ & $* * *$ & $* * *$ & $* * *$ & $* *$ & 0 & $*$ & 0 & 0 & 0 & I \\
\hline A2 & $\mathrm{T} 2$ & gorC & $* * *$ & $* * *$ & $* * *$ & $* * *$ & $* *$ & 0 & $*$ & 0 & 0 & * & 0 \\
\hline A2 & $\mathrm{T} * 3$ & pbog & $* *$ & $*$ & $* *$ & $* *$ & $* *$ & $*$ & 0 & 0 & 0 & I & 0 \\
\hline A1 & $\mathrm{T} 4$ & oakVi & 0 & 0 & 0 & 0 & 0 & 0 & $*$ & $* *$ & $* *$ & $* *$ & 0 \\
\hline $\mathrm{A} 1$ & $\mathrm{~T} * 5$ & $\operatorname{ash} \mathrm{T}$ & 0 & 0 & 0 & 0 & 0 & $* *$ & $* *$ & $* * *$ & $* * *$ & $* *$ & $* *$ \\
\hline
\end{tabular}

Four frequent species and eight rare species have low IndVal values and were not indicator species of the main groups of sites. The frequent species were Oligolophus hansenii (KRAEPELIN, 1896), Nemastoma hankiewiczii (KULCZYNSKI, 1909), Odiellus simplicipes (SIMON, 1879) and Odiellus seoanei (SIMON, 1878). O. simplicipes is the actual name of $O$. ruentalis (KRAUS, 1961). O. seoane $i$ is the new identification of specimens previously attributed to O. spinosus (BosC, 1792) (MERINO SÁINZ \& ANADÓN 2008).

\section{DISCUSSION}

The first important result is that each phytosociological association does not have a specific harvestmen fauna: a different botanical

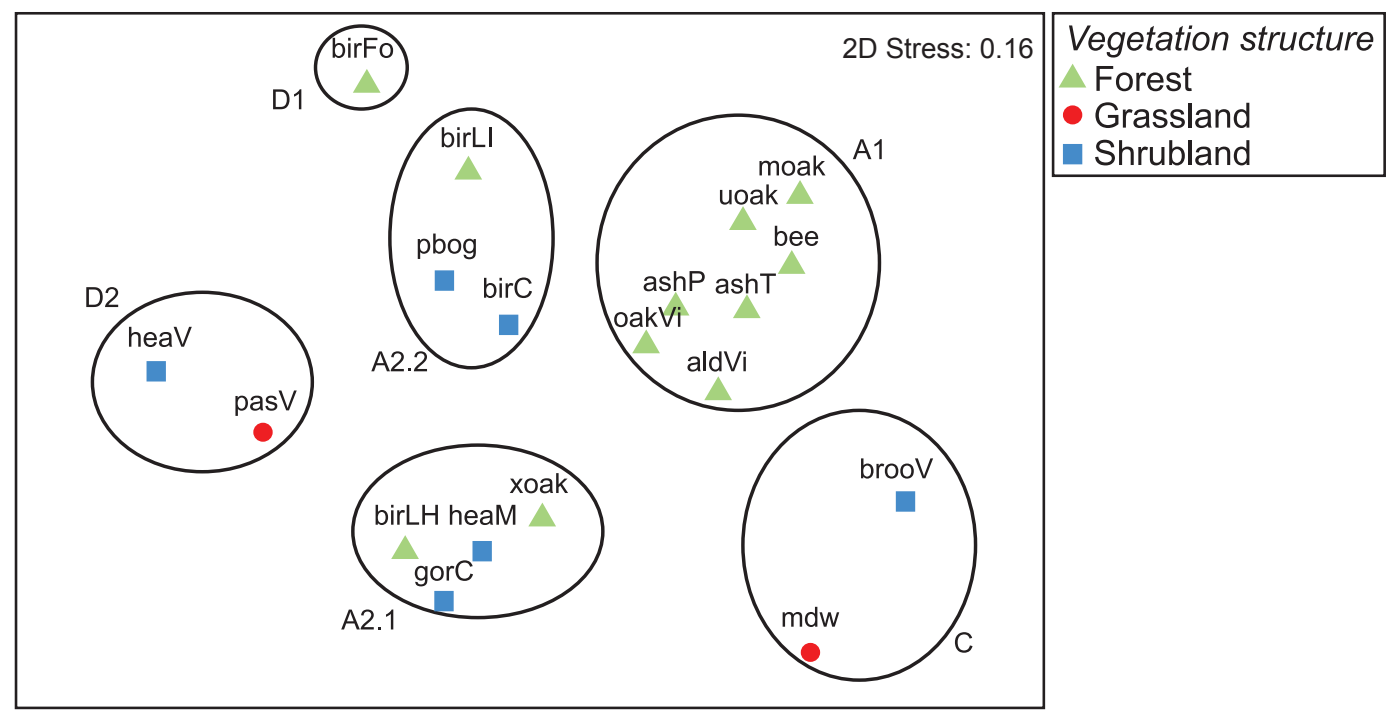

Fig. 4. - MDS of sites showing the vegetation structure and the groups of sites obtained with the cluster analysis. 
TABLE 5

Species contribution to the internal similarity of the clusters of sites (SIMPER). Distribution: Hol = holarctic; Eur = European; IE = Iberian endemic.

\begin{tabular}{|ccccc|}
\hline Sites cluster & A1 & $\mathbf{A 2 . 1}$ & $\mathbf{A 2 . 2}$ & Distrib \\
Average similarity & $\mathbf{6 1 . 5 9}$ & $\mathbf{6 3 . 6 0}$ & $\mathbf{5 1 . 4 6}$ & \\
Spp. contribution & $\mathbf{\%}$ & $\mathbf{\%}$ & $\mathbf{\%}$ & \\
\hline Leiobunum rotundum (LATREILLE, 1798) & 21.01 & & & Eur \\
Paroligolophus agrestis (MEADE, 1855) & 19.53 & & 9.87 & Hol \\
Leiobunum blackwalli MEADE, 1861 & 16.81 & & & Eur \\
Oligolophus hansenii (KRAEPELIN, 1896) & 9.56 & & 43.96 & Eur \\
Homalenotus laranderas GRASSHOFF, 1959 & 9.16 & 8.06 & & IE \\
Trogulus nepaeformis (SCOPOLI, 1763) & 7.8 & & & Eur \\
Ischyropsalis hispanica ROEWER, 1953 & 6.68 & & & IE \\
Phalangium opilio LINNAEUS, 1758 & & 42.34 & 39.24 & Hol \\
Odiellus simplicipes (SIMON, 1879) & & 26.39 & & IE \\
Odiellus seoanei (SIMON, 1878) & & 20.32 & & IE \\
Homalenotus laranderas GRASSHOFF, 1959 & & 8.06 & & IE \\
\hline
\end{tabular}

characterization of the studied sites alone does not imply a differentiated harvestmen assemblage. The assemblages of forested areas are neither similar among them nor different to those of open habitats. Rather, there are two main clusters of sites, both including different forest sites: each cluster of sites shares different indicator species. Species richness and abundance vary according to the type of forest. Muniellos forests had 8.27 \pm 3.07 harvestmen species on average, while open habitats including different types of shrubland and a meadow had a much lower diversity of $4.0 \pm 0.72$. Abundance was highest in the gallery forests, the beech forest and the lowest altitude birch forest. Sessile oak forests and the mixed forest had medium abundances.

CURTiS \& MACHADO (2007) compiled data from different studies and showed that the average species richness of harvestmen in forested habitats is 2.8 times higher than in open habitats. They explain this on the basis of seasonal variations in abiotic factors in open habitats, mainly temperature and humidity, which may restrict the occurrence of many harvestmen species in this habitat, and the more complex structure of forested habitats, which may provide a greater diversity of suitable micro-habitats. The diversity of micro-habitats and food (Collembola and Acari) is also greater in forest habitats (see Mitov 2007).

\section{Discontinuities: changes in harvestmen fauna and vegetation}

Which factors are responsible for the variation? Orientation seems to have a decisive influence on harvestmen assemblages. An abrupt border was found between the two main clusters of sites. The abrupt change in southern versus northern orientation in the wedged valleys on Mount Muniellos results in a variation in xerophilous versus ombrophilous sessile oak forests, which was also reflected in the harvestmen fauna.

There is a border in the corner, between the shady (P2 and P3) and sunny (P8 and P1) slopes, along the path to the Mount Muniellos lagoons (Fig. 1). The vegetation changes abruptly there, though sessile oaks (Quercus petraea) cover P1, P2 and P3. The sessile oaks at P1 are shorter and sparser than at P3 and P2. The floristic composition of P1 is also substantially different from P2 and P3. Plot P1 and the heath P8 belong to the same series of vegetation (FERNÁNDEZ PRIETO \& BUENO SÁNCHEZ 1996); the xerophilous sessile oak forest series. 


\section{TABLE 6}

Indicator species of cluster A1 and A2 with their specificity and fidelity values. $P=$ significance level. Distribution: $\mathrm{Hol}=$ holarctic; Eur = European; IE = Iberian endemic.

\begin{tabular}{|cccccc|}
\hline Cluster A1 & Specificity & Fidelity & $\begin{array}{c}\text { Indicator } \\
\text { Value }\end{array}$ & $\mathbf{p}$ & Distrib \\
\hline Leiobunum rotundum (LATREILLE, 1798) & 0.9737 & 1.000 & 0.987 & $0.001^{* * *}$ & Eur \\
Leiobunum blackwalli MEADE, 1861 & 0.8889 & 1.000 & 0.943 & $0.001 * * *$ & Eur \\
Paroligolophus agrestis (MEADE, 1855) & 0.8539 & 1.000 & 0.924 & $0.0011^{* * *}$ & Hol \\
Trogulus nepaeformis (SCOPOLI, 1763) & 0.9412 & 0.8571 & 0.898 & $0.001 * * *$ & Eur \\
Homalenotus laranderas GRASSHOFF, 1959 & 0.7931 & 1.000 & 0.891 & $0.003 * *$ & IE \\
Ischyropsalis hispanica ROEWER, 1953 & 0.7407 & 0.8571 & 0.797 & $0.017^{*}$ & IE \\
\hline Cluster A2 & & & & & \\
\hline Phalangium opilio Linnaeus, 1758 & 0.7885 & 0.8571 & 0.822 & $0.015^{*}$ & Hol \\
\hline
\end{tabular}

The change in faunal composition in this border is supported by three different analyses: (a) the cluster analyses (Figs 3-4) separates the harvestmen assemblages of shady plots (P3 and $\mathrm{P} 2$, in $\mathrm{A} 1)$ from those of sunny plots (P1 and $\mathrm{P} 8$, in A2); (b) the ANOSIM analyses (Table 4) yielded significant pairwise differences $(* * *)$ between $\mathrm{P} 3$ and $\mathrm{P} 2$, relative to $\mathrm{P} 1$ and $\mathrm{P} 8$; and between the cluster A1 and A2; (c) the six indicator species of A1 are different from the only indicator species of A2. So the local hard boundary (FORMAN 2006) between the faunas must be located along the confluence of the sunny and the shady slopes.

The mixed forest of maples and sessile oaks (P2) and the ombrophilous sessile oak forest (P3) represent two different mature forests very close to each other belonging to cluster A1 with the same indicator species (Table 6).

Sites with a richer soil harboured a higher species richness. The mixed forest, the gallery forests, -ash tree forest and alder tree forestand the beech forest, which all share a rich soil, showed the highest harvestmen species richness (11-13 species/site). Higher soil richness is indicated by the presence of the tree species ash, maple, lime (Tilia platyphyllos) and elm (Ulmus glabra), which are known to prefer rich soils. These sites also have higher harvestmen species richness and higher true diversity (Table 2 ). Those tree species grow at the bottom of valleys and over landslides, where there is high soil aeration and humidity, facilitating good decomposition of organic matter and producing mull humus (FERNÁNDEZ PRIETO \& BUENO SÁNCHEZ 1996). The influence of soil factors on the species richness of scorpions has already been documented (PoLIS 1990).

Gallery forests, due to their special position in the valleys, have a richer soil since they usually accumulate particulate matter and mineral nutrients carried overland by the surface flow of water (FORMAN 2006). They are especially important in nutrient-poor locations more typical of uplands, as is the case in Muniellos. Also the sampled beech forest was situated at lower altitudes in the Muniellos valley. The high species richness of the mixed forest is related to its richer soil over a landslide. This woodland constitutes an island of abundant maples surrounded by ombrophilous sessile oak forest, with poorer soils.

The mixed forest P2 hosts four endemic rare species Sabacon franzi (RoEWER, 1953), Nemastomella dentipatellae (DRESCO, 1967), Paramiopsalis sp. and Hadziana clavigera (SIMON, 1879), all endemic to the north of the Iberian Peninsula. H. clavigera is the actual name of Peltonychia clavigera (SIMON, 1879) (KURY \& MENDES 2007). The presence of stenotopic taxa at P2 noticeably increases the species richness of this site with respect to $\mathrm{P} 3$. 
Three European species considered to be rare in this landscape were found in the ash tree forest: Anelasmocephalus cambridgei (WESTWOOD, 1874), Gyas titanus (SIMON, 1879), and Dicranopalpus sp. Another European species Megabunus diadema (FABRICIUS, 1779) was found over the highest sampled site in an open birch forest.

\section{Comparison with other faunas}

The harvestmen fauna of Muniellos has six species in common with the fauna of San Juan de la Peña in the Pyrenees Mountains (RAMBLA 1985), where eleven species have been found. There, Oligolophus hansenii is the most abundant species. In the Pyrenees Quercus ilex forest and Quercus faginea forest, both typical of the Mediterranean climate, have fewer species than the other forests and their dominant species differ. In Muniellos, the species richness was higher (6-13) at low and medium altitude woodlands, maximal (10-13) in gallery, mixed and beech forests; xerophilous sessile oak forests as well as the birch forests (which grow at higher altitude) have medium (6-8) species richness; fewer species, $\leq 5$, were found in open highaltitude birch forests (above 1,340 m) and in all open habitats (Table 2). In Muniellos O. hansenii was present in most of the forests and it was not an indicator species of any cluster.

Studies of some heath-gorse shrublands (RosA GARCíA et al. 2009a, b) in Illano (Asturias), 40 $\mathrm{km}$ north of Muniellos, have found nine species also present in Muniellos. Thus, there is a basic pool of species in the area, though with different relative frequencies in the two territories.

Mitov \& Stoyanov (2005) studied and modelled ecological profiles of harvestmen species on the Vitosha Mountain, Bulgaria, and concluded that altitude contributes the most to explaining the ecological requirements of harvestmen, followed by soil type, vegetation belt (both presenting a very similar structure to that of the altitude zone) and exposure.
Vegetation belt, habitat type, soil type and light conditions are more strongly associated with the second ordination axis. The similar patterns of soil type, altitude zone and vegetation belt are due to strong interdependence between these factors (Mitov \& STOYANOV 2005). Geographical exposition and soil richness in Vitosha were hence important, as it was found in Muniellos. The aforementioned study found two main groups of species: species with regionalwide distribution and species virtually restricted to low-altitude areas. In Muniellos the frequent species are either holarctic, European or Iberian endemic, and rare species are European, or Iberian endemic.

\section{ACKNOWLEDGEMENTS}

We are grateful to FJ Ocharan, co-director, and VX Melero, S Monteserín, R Ocharan, R Rosa and MT Vázquez, co-authors of the Muniellos Catalogue of Invertebrates Project for sampling. Project supported by Consejería de Medio Ambiente del Principado de Asturias: SV-PA-00-01 (INDUROT), SV-PA-01-06, SVPA-02-08 and SV-PA-03-13. We thank Carlos Prieto for his help in taxonomic and identification enquiries, Jordi Moya-Laraño, who helped to improve this manuscript, Prieto Fernández for kindly solving doubts concerning vegetation and F González Taboada for obtaining the species indicator values.

\section{REFERENCES}

Acosta LE \& GuERRERo EL (2011). Geographical distribution of Discocyrtus prospicuus (Arachnida: Opiliones: Gonyleptidae): Is there a pattern? Zootaxa, 3043:1-24.

Almeida-Neto M, Machado G, PinTO-DA-RochA R, GiARETTA AA (2006). Harvestman (Arachnida: Opiliones) species distribution along three Neotropical elevational gradients: an alternative rescue effect to explain Rapoport's rule? Journal of Biogeography, 33:361-375.

ANAdÓNA, OCHARAN FJ, MELERO VX, MONTESERÍN S, OCHARAN R, Rosa R, VÁzQUEz M (2002). Metodología para la elaboración del catálogo de 
los invertebrados de la Reserva de la Biosfera de Muniellos (Asturias, N. de España). Boletín de Ciencias de la Naturaleza (RIDEA), 48:291-305.

Bragagnolo C, Nogueira AA, Pinto-DAROCHA R, PARDINI R (2007). Harvestmen in an Atlantic forest fragmented landscape: Evaluating assemblage response to habitat quality and quantity. Biological Conservation, 139(3-4):389400.

ClARKe KR \& Gorley RN (2006). PRIMER v6: User Manual/Tutorial. PRIMER-E Ltd. Plymouth.

CURTIS DJ \& MACHADO G (2007). Ecology. In: Harvestmen. The biology of Opiliones, Pintoda-Rocha R, Machado G \& Giribet G, (eds). Cambridge, Massachusetts. Harvard University Press, pp. 280-308.

DE CÁCERES M \& JANSEN F (2014). Indicspeciespackage 1.7.32014-07-10. Studying the statistical relationship between species and groups of sites. GPL.

De CÁCERES M \& LEGENDRE P (2009). Associations between species and groups of sites: indices and statistical inference. Ecology, 90(12):3566-3574.

DíAZ GONZÁlez TE \& FERNÁNDEZ PRIETO JA (1994). El Paisaje Vegetal de Asturias. Guía de la IX Excursión Internacional de Fitosociología. Itinera Geobotanica, 8:5-242.

DUFRÊNE M \& LEGENDRE P (1997). Species assemblages and Indicator Species: The need for a Flexible Assymmetrical Aproach. Ecologycal Monographs, 67(3):345-366.

FERNÁNDEZ PRIETO JA \& BUENO SÁNCHEZ A (1996). La Reserva Integral de Muniellos: Flora y Vegetación. Cuadernos de Medio Ambiente Naturaleza 1. Oviedo: Principado de Asturias, Consejería de Agricultura, $84 \mathrm{pp}$.

FORMAN RTT (2006). Land mosaics. The ecology of landscapes and regions. Cambridge: Cambridge University Press, 632 pp.

HILL MO (1973). Diversity and Evenness: A Unifying Notation and Its Consequences. Ecology, 54(2): 427-432.

Hortal J, García-Pereira P \& García-Barros E (2004). Butterfly species richness in mainland Portugal: Predictive models of geographic distribution patterns. Ecography, 27:68-82.

HORTAL J \& LOBO JM (2005). An ED-based protocol for optimal sampling of biodiversity. Biodiversity and Conservation, 14:2913-2947.

JIMÉNEZ-VALVERDE A \& HORTAL J (2003). Las curvas de acumulación de especies y la necesidad de evaluar la calidad de los inventarios biológicos. Revista Ibérica de Aracnología, 8:151-161.

Jost L (2007). Partitioning diversity into independent alpha and beta components. Ecology, 88:24272439.

Komposch C (2000). Harvestmen and spiders in the Austrian wetland "Hörfeld-Moor" (Arachnida: Opiliones, Araneae). In: GAJdos P \& PEKÁR $\mathrm{S}$ (eds). Proceedings of the 18th European Colloquium of Arachnology, Stará Lesná, 1999. Ekológia (Bratislava), 19 (Supplement 4):65-77.

Komposch C \& GRUBer J (1999). Vertical distribution of harvestmen in the Eastern Alps (Arachnida: Opiliones). Bulletin British Arachnological Society, 11(4):131-135.

KURY AB \& MENDES AC (2007). Taxonomic status of the European genera of Travuniidae (Arachnida, Opiliones, Laniatores). Munis Entomology and Zoology Journal, 2(1):1-14.

LipovseK S, NovaK T, Sencic L \& Slana L (1996). AContribution to the Biology and Ecology of Gyas annulatus (Oliver, 1791) and G. titanus Simon, 1879, Phalangiidae, Opiliones. Znanstvena revija, 8:129-136.

MERINO SÁINZ I \& ANADÓN A (2008). La fauna de Opiliones (Arachnida) de la Reserva Integral Natural de Muniellos (Asturias) y del Noroeste de la Península Ibérica. Boletín SEA, 43:199-210.

MERINO SÁINZ I \& ANADÓN A (2009). Primera cita del género Paramiopsalis Juberthie, 1962 (Arachnida: Opiliones, Sironidae) para Asturias (España). Boletín SEA, 45:556-558.

MERINO-SÁINZ I, ANADÓN MA \& TORRALBABURRIAL A (2013). Harvestmen of the BOS Arthropod Collection of the University of Oviedo (Spain) (Arachnida, Opiliones). Zookeys, 341:2136.

MiLnE BT (1988). Measuring the fractal geometry of landscapes. Applied Mathematics and Computation, 27:67-79.

Mitov P (1997). Preliminary investigations on the spatial distribution of the harvestmen (Opiliones, Arachnida) from Vitosha Mt. (SW Bulgaria). In: Proceedings $16^{\text {th }}$ European Colloque Arachnology. Siedlce, Poland, pp. 249-258.

Mitov P (2007). Spatial Niches of Opiliones (Arachnida) from Vitosha Mountains, Bulgaria. In: Fet V \& Popov A (eds). Biogeography and Ecology of Bulgaria, pp. 423-446. 
Mitov PG \& StoyAnOV IL (2005). Ecological profiles of harvestmen (Arachnida, Opiliones) from Vitosha Mountain (Bulgaria): a mixed modelling approach using GAMS. Journal of Arachnology, 33:256-268.

MUSTER C (2001). Biogeographie von Spinnentieren der mittleren Nordalpen (Arachnida: Araneae, Opiliones, Pseudoscorpiones). Verhandlungen des Naturwissenschaftlichen Vereins in Hamburg (NF), 39:5-196.

OCHARAN LARRONDO FJ, ANADÓN ÁlVAREZ, Melero Cimas VX, Monteserín Real S, OCHARAN IBARRA R, ROSA GARCÍA $\mathrm{R} \&$ VÁZQuez FELECHOSA MT (2003). Invertebrados de la Reserva Natural Integral de Muniellos, Asturias. Oviedo: KRK ediciones. 355 pp.

Paschetta M, La Morgia V, Masante D, Negro M, Rolando A \& ISAiA M (2013). Grazing history influences biodiversity: a case study on ground dwelling arachnids (Arachnida: Araneae, Opiliones) in the natural Park of Alpi Maritime (NW Italy). Journal Insect Conservation, 17:339356.

PETERKEN GF (1993). Woodland Conservation and Management. London: Chapman and Hall, 396 pp.

PINTO-DA-RochA R \& DA SILVA MB (2005). Faunistic similarity and historic biogeography of the harvestmen of southern and southeastern Atlantic rain forest of Brazil. Journal of Arachnology, 33: 290-299.

Polis GA (1990). Ecology. In: Polis GA (ed.). The biology of Scorpions. Stanford University Press, California:247-293.

Principado de Asturias (2001). Consejería de Medio Ambiente. Muniellos. Reserva de la Biosfera. Oviedo: Fundación Oso de Asturias, 83 pp.

R Development Core Team (2014). R: a language and environment for statistical computing. "Sock it to Me" The R Foundation for Statistical Computing Platform: i386-w64-mingw32/i386 (32-bit).

RAMBla M (1985). Artrópodos epigeos del Macizo de San Juan de la Peña (Jaca, Huesca). Pirineos, 124: $87-169$.

RICKLEFS RE (1987). Community diversity: relative roles of local and regional processes. Science, 235:167-171.

RICKLEFS RE (2004). A comprehensive framework for global patterns in biodiversity. Ecology letters, $7: 1-15$.
ROSA GARCÍA R, JÁUREGUI BM, GARCÍA U, OSORO K \& CELAYA R (2009a). Effects of livestock breed and grazing pressure on ground-dwelling arthropods in Cantabrian heathlands. Ecological Entomology, 34:466-475.

ROSA GARCía R, JÁUREGUI BM, GARCía U, OSORO K \& CELAYA R (2009b). Responses of Arthropod Fauna Assemblages to Goat Grazing Management in Northern Spanish Heathlands. Environmental Entomology, 38(4):985-995.

StatSoft (2001). STATISTICA (data analysis software system and computer program manual). Version 6. Tulsa, OK.

Stol I (2003). Distribution and ecology of harvestmen (Opiliones) in the Nordic countries. Norwegian Journal of Entomology, 50:33-41.

STOL I (2004). Biotope preferences and size of Lacinius ephippiatus (C.L. Koch, 1835) (Opiliones: Phalangidae) at Karmǿy, Western Norway. Norwegian Journal of Entomology, 51:203-211.

TUOMIsto H (2010). A diversity of beta diversities: straightening up a concept gone awry. Part 1 . Defining beta diversity as a function of alpha and gamma diversity. Ecography, 33:2-22.

TSURUSAKI N, TAKANASHI M, NAGASE N \& SHIMADA T (2005). Fauna and biogeography of harvestmen (Arachnida: Opiliones) of the Oki Islands, Japan. Acta Arachnologica, 54(1):51-63.

WiEnS JJ \& DONOGHUE MJ (2004). Historical biogeography, ecology and species richness. Trends in Ecology and Evolution, 19:639-644.

ZINGERLE V (1997). Epigäische Spinnen und Weberknechte im Naturpark Puez-Geisler (Dolomiten, Südtirol) (Araneae, Opiliones). Berichte des NaturwissenschaftlichMedizinischen Vereins in Innsbruck, 84:171-226.

ZINGERLE V (1999). Epigäische Spinnen- und Weberknechte im Naturpark Sextner Dolomiten und am Sellajoch (Südtirol, Italien) (Araneae, Opiliones). Berichte des NaturwissenschaftlichMedizinischen Vereins in Innsbruck, 86:165-200.

Received: June 28th, 2014

Accepted: February 10th, 2015

Branch editor: Frederik Hendrickx 